\title{
Pembelajaran Tata Bangunan dan Lingkungan di Desa Cikole Kecamatan LEMBANG, KABUPATEN BANDUNG BARAT
}

\author{
THE LEARNING OF BUILDINGS ARRANGEMENT AND ENVIRONMENTS IN THE CIKOLE \\ VILLAGE, LEMBANG, BANDUNG BARAT DISTRICT
}

\author{
${ }^{1}$ Hilwati Hindersah, ${ }^{2}$ Ina Helena Agustina, ${ }^{3}$ Imam Indratno \\ ${ }^{1,2,3}$ Program Studi Perencanaan Wilayah dan Kota, UNISBA, Jl. Tamansari No. 1 Bandung 40116 \\ e-mail: ${ }^{1}$ hilwati@gmail.com, ${ }^{2}$ inahelena66@gmail.com, ${ }^{3}$ akudandiriku1@gmail.com.
}

\begin{abstract}
Learning of buildings arrangement and environments in the Cikole village is an training effort to increase the understanding of the community village about the importance of manage housing environment well. Method used is the method training by measuring their level of understanding through pre test and post test. Pre test results show that the buildings and environments is of buildings and environments at the present time, which is actually not in line with the building regulation. We do training on substance of good buildings and environments according engineering. The post test shows that understanding of the importance of well-ordered environment in their neighborhood increased significantly. It can be concluded that the teaching process of rural buildings and environments be incredibly important to give the fundamental understanding to a good neighborhood . But they have to be followed up to get to the action of caring to keep of buildings and environments well.
\end{abstract}

Keywords: learning, arrangement, building, environment

\begin{abstract}
Abstrak. Pembelajaran Tata Bangunan dan Lingkungan di Desa Cikole merupakan upaya pelatihan untuk meningkatkan pemahamam masyarakat desa tentang pentingnya menata lingkungan perumahan dengan baik. Metode yang digunakan adalah metode pelatihan dengan mengukur tingkat pemahaman mereka melalui pre test dan post test. Hasil pre test menunjukkan bahwa tata bangunan dan lingkungan yang baik adalah tata bangunan dan lingkungan yang ada saat ini, yang sebenarnya belum sesuai ketentuan bangunan. Kemudian dilakukan pelatihan tentang substansi tata bangunan dan lingkungan yang baik sesuai teknik rekayasa maka hasil post test menunjukkan bahwa pemahaman tentang pentingnya lingkungan yang tertata dengan baik di lingkungan tempat tinggal mereka meningkat cukup signifikan. Dengan demikian maka dapat disimpulkan bahwa proses pembelajaran tata bangunan dan lingkungan perdesaan menjadi sangat penting untuk memberikan pemahaman mendasar terhadap suatu lingkungan yang baik. Akan tetapi harus ditindak lanjuti untuk sampai pada tindakan "peduli" terhadap menjaga tata bangunan dan lingkungan yang baik tersebut.
\end{abstract}

Kata kunci: pembelajaran, tata, bangunan, lingkungan

\section{Pendahuluan}

Kawasan perdesaan merupakan kawasan yang memiliki peran strategis dalam mempertahankan ketahanan pangan nasional. Upaya untuk tetap mempertahankan eksistensi lahan pertanian merupakan tantangan berat (Sargent, et.al. 1991). Karena itu kecenderungan perubahan lahan dari pertanian ke non pertanian menjadi fokus perhatian agar tidak mengganggu ketahanan pangan nasional. Akan tetapi kecenderungan perubahan itu tidak dapat dihindari terutama pada kawasan perdesaan yang memiliki aksesibilitas dengan kawasan perkotaan. Demikian halnya dengan Desa 
Cikole di Kecamatan Lembang Kabupaten Bandung Barat. Lokasi nya yang relatif berdekatan dengan Kota Bandung, merupakan kawasan pariwisata dengan alternatif jaringan jalan yang sangat variatif mengakibatkan kawasan perdesaan ini berubah fungsi secara perlahan. Berdasarkan data tahun 2009 terjadi pertambahan jumlah luas permukiman sebesar 102,392 Ha menjadi 119,541 Ha pada tahun 2011. Pertambahan luas permukiman ini memiliki konsekuensi terhadap pertambahan tutupan lahan (lahan terbangun) di Desa Cikole.

Desa Cikole berada di Kecamatan Lembang Kabupaten Bandung Barat yang masuk dalam fisiografi Bandung Utara. Secara fisiografi Kecamatan Lembang adalah kecamatan yang masuk dalam kawasan yang harus dibatasi tutupan lahannya (lahan terbangun) karena dapat mengakibatkan banjir di bagian Selatan Bandung. Bertambah luasnya kawasan permukiman di Desa Cikole identik dengan bertambahnya bangunanbangunan rumah. Pertambahan bangunan tidak hanya rumah melainkan juga bangunanbangunan dengan fungsi lainnya seperti fungsi perdagangan. Pertambahan bangunan yang tidak terkendali mengakibatkan menurunnya fungsi lingkungan seperti adanya degradasi lingkungan. Degradasi lingkungan dapat mengakibatkan menurunnya kualitas hidup manusia yang menempatinya. Selain itu dapat mengakibatkan kebencanaan yang ditimbulkan karena perilaku manusia terhadap lingkungannya. Berdasarkan temuan Tim Kader Pemberdayaan Masyarakat, terungkap adanya tingkat kepedulian masyarakat terhadap lingkungan yang rendah (Hindersah, et.al. 2014). Dengan demikian masyarakat Desa Cikole membutuhkan suatu peningkatan pengetahuan melalui pembelajaran tata bangunan dan lingkungan yang dilaksanakan dalam bentuk pelatihan

Masalah perkembangan permukiman di Desa Cikole Kecamatan Lembang Kabupaten Bandung Barat memiliki konsekuensi pada pertambahan bangunan yang ada di Desa tersebut. Berdasarkan Undang-undang No 28 Tahun 2002 tentang Bangunan Gedung dan Peraturan Pemerintah No 36 Tahun 2005 Tentang Peraturan Pelaksanaan UU No 28 Tahun 2002, bangunan-bangunan tersebut membutuhkan suatu persyaratan fisik tertentu. Dengan demikian masyarakat membutuhan pengetahuan dalam upaya memberikan ruang yang aman, nyaman, produktif dan berkelanjutan. Tata Bangunan adalah produk dari penyelenggaraan bangunan gedung beserta lingkungannya sebagai wujud pemanfaatan ruang, meliputi berbagai aspek termasuk pembentukan citra/karakter fisik lingkungan, besaran, dan konfigurasi dari elemen-elemen: lokasi dan orientasi bangunan, blok, kaveling/petak lahan, serta ketinggian dan elevasi lantai bangunan, yang dapat menciptakan dan mendefinisikan berbagai kualitas ruang kota yang akomodatif terhadap keragaman kegiatan yang ada, terutama yang berlangsung dalam ruang-ruang publik. Tata Bangunan juga merupakan sistem perencanaan sebagai bagian dari penyelenggaraan bangunan gedung beserta lingkungannya, termasuk sarana dan prasarananya pada suatu lingkungan binaan baik di perkotaan maupun di perdesaan sesuai dengan peruntukan lokasi yang diatur dengan aturan tata ruang yang berlaku dalam RTRW Kabupaten/Kota berikut rencana rincinya. Batasan/lingkup pelatihan ini hanya sebatas upaya agar masyarakat dapat memahami prinsip pengaturan suatu bangunan dan lingkungan berdasarkan pada materi yang ditetapkan.

Substansi untuk pelatihan dikumpulkan dari berbagai sumber kemudian diolah dalam upaya penyesuaian dengan kondisi lapangan. Terutama untuk membuat pedoman bangunan dan lingkungan sehat di kawasan Desa Cikole. Materi yang digunakan pada pelatihan ini berupa UU No 28 Tahun 2002 tentang Bangunan Gedung, lalu Peraturan Pemerintah No 36 Tahun 2005 tentang Pelaksanaan UU No. 28 Tahun 2002. Materi pelatihan juga merujuk pada Peraturan Menteri PU No 06/PRT/M/2007 tentang 
Pedoman Rencana Tata Bangunan dan Lingkungan dan Keputusan Menteri Kesehatan Republik Indonesia No. 829/Menkes/SK/VII/1999 tentang Rumah Sehat. Selain itu digunakan beberapa referensi yang relevan dengan substansi materi untuk wilayah studi. Selanjutnya materi-materi tersebut disesuaikan kembali untuk kebutuhan kawasan perdesaan. Dengan demikian maka substansi materi pelatihan dapat dijadikan pedoman untuk pelatihan tata bangunan dan lingkungan di desa pegunungan. Adapun substansi pembelajaran materi tata bangunan dan lingkungan tersebut dibagi dalam 2 pembahasan yaitu pembelajaran tata bangunan dan pembelajaran lingkungan.

\subsection{Pembelajaran Tata Bangunan}

\section{Perencanaan Rumah Dari Segi Kenyamanan Tinggal}

Ada beberapa pendapat bahwa "perumahan di desa tidak usah setaraf dengan perumahan di kota dalam bentuk dan besarnya". Hal ini mempertimbangkan agar ciriciri khas perdesaannya yang baik tetap terpelihara. Mekipun demikian kiranya dapat digunakan standar seperti berikut.

\section{a. Jumlah ruangan}

Ruangan yang diperlukan untuk satu keluarga yang beranggotakan 5 orang, yaitu ayah, ibu, serta 3 orang anak akan memerlukan hal-hal sebagai berikut:

- Dua ruang tidur;

- Satu ruang keluarga;

- Satu ruang makan (ruang keluarga dan ruang makan dapat dijadikan dalam satu ruangan).

\section{b. Ukuran ruangan}

Ukuran ruangan sangat bergantung kepada kebutuhan. Perencanaannya tergantung pada selera atau keinginan pemilik dan kultur yang ada pada desa setempat. Bilamana kultur setempat belum dipandang cukup memenuhi persyaratan kesehatan dan kenyamanan, maka perencanaannya yang digunakan untuk membangun rumah di daerah tersebut adalah perencanaan rumah yang bersifat umum.

\section{c. Rancangan Ruang Luar/Halaman}

Minimalkan penggunaan material keras (beton, aspal) untuk menutup permukaan halaman, taman, atau parkir tanpa adanya peneduh. Material keras yang terkena radiasi matahari langsung akan menaikkan suhu udara di sekitar rumah dan akhirnya membuat ruangan di dalam rumah menjadi panas.

\section{Perencanaan Rumah dari Segi Konstruksi dan Segi Teknis}

Secara umum, dari segi konstruksi dan segi teknis hendaknya diperhatikan halhal yang akan diuraikan di bawah ini.

\section{a. Jendela dan Lubang Ventilasi}

Rumah yang tanpa jendela, untuk ukuran dan persyaratan pada saat ini bukanlah kriteria rumah yang sehat dan sempurna, sebab kriteria rumah yang sehat mewajibkan adanya jendela dan ventilasi. Ukuran jendela dapat disesuaikan dengan ukuran ruangan. Ambilah sedikitnya luas jendela yang rata-ratanya $\frac{1}{2}$ atau 4\% dari luas seluruh dinding ruangan. Sebaiknya jendela tersebut diberi kaca sehingga meskipun tertutup, cahaya matahari tetap dapat masuk. Akan lebih baik lagi bilamana di atas jendela tersebut dibuat lubang ventilasi, umpamanya merupakan ruji-ruji seluas $\frac{1}{5}$ dari luas seluruh jendela. Buatlah juga lubang ventilasi di bawah atap sehingga udara dari luar dapat mengalir dan 
menggerakan udara yang ada di bawah atap. Lubang ventilasi tersebut hendaknya diberi penutup yang jarang seperti saringan atau anyaman kawat sebagai pencegah masuknya burung atau kelelawar. Selain itu buatlah juga pada sebelah atas dinding-dinding pemisah di dalam rumah atau bangunan beberapa lubang ventilasi. Ini dimaksudkan agar seluruh rumah atau bangunan tersebut mendapatkan pergerakan udara yang baik.

b. Lantai, Dinding, dan Atap

Bilamana memungkinkan, gunakanlah bahan bangunan yang lebih kuat, umpamanya mengganti tiap-tiap bambu dengan tiang-tiang kayu. Demikian juga penutup atap, hindarilah jenis atap yang mudah menjadi sarang tikus dan mudah dimakan api seperti alang-alang. Gantilah dengan atap genting, seng, atau sirap.

c. Persediaan Air

Kebutuhan air untuk kehidupan manusia sehari-hari sangatlah penting. Air di daerah perdesaan dapat diambil dari beberapa sumber, salah satunya adalah pancuran, kali, sumur, atau penampungan air hujan. Dari manapun air itu berasal, usahakanlah air tersebut bersih dan tidak bau. Untuk air minum, masak terlebih dahulu, dan dapat disimpan di dalam kendi atau tempayan. Bilamana sumber air diambil dari sumur, hendaknya sumur tersebut:

- Dibuat dekat dapur;

- Dipasang dinding selubung setinggi kurang lebih $70 \mathrm{Cm}$ yang terbuat dari bata atau bambu demi keamanan untuk anak-anak kecil dan binatang ternak;

- Berilah sumur tersebut penutup, sehingga air tidak mudah tercemar; dan

- Jarak antara sumur dengan lubang kakus sedikitnya adalah 10 Meter.

Bilamana persediaan air untuk mandi dialirkan ke kamar mandi yang tersendiri, bak kamar mandi dapat dibuat dari dinding bata yang disemen, minimal berukuran $50 \times 50 \times 50 \mathrm{~cm}$.

\section{d. Kakus}

Setiap rumah masing-masing wajib memiliki kakus sesuai anjuran internasional dalam rangka meningkatkan pembangunan lingkungan perumahan yang sehat. Kakus-kakus umum dapat dibangun, asal kebersihan dan cara pembuangannya memenuhi persyaratan kesehatan. Petunjuk-petunjuk dari Dinas Kesehatan setempat hendaknya diperhatikan sepenuhnya di dalam membangun lingkungan yang sehat dan resik.

\subsection{Pembelajaran Lingkungan}

\section{Pemahaman Iklim Terhadap Suatu Bangunan}

Indonesia termasuk apa yang disebut daerah yang beriklim panas-lembab. Udaranya terdiri dari udara pegunungan atau dataran tinggi, dan udara perairan atau daerah pantai atau dataran rendah. Pada umumnya keadaan iklim tersebut ialah panas terik pada musim kemarau dan agak sejuk pada musim hujan. Iklim ditentukan pula oleh keadaan matahari dan keadaan angin. Oleh karena itu, kualitas dan penataan bangunan harus tahan terhadap cuaca panas sekaligus terpaan hujan.

\section{Perencanaan Rumah Terhadap Sinar Matahari}

Jalur jalan matahari mempengaruhi cahaya siang dan teriknya sinar matahari. Cahaya siang yang menyilaukan dan terik sinar yang panas dapat dikurangi dengan pengaturan dan penentuan besarnya jendela. Di samping itu dapat pula dengan penanaman pepohonan, bayangan pepohonan tersebut dapat meneduhkan udara sekeliling rumah atau bangunan. Bila keadaan 
memungkinkan, arahkanlah rumah atau bangunan sedemikian rupa sehingga luas dinding-dinding yang disinari matahari sesedikit mungkin. Umpamanya dengan menghadapkan ujung rumah atau bangunan kurang lebih pada arah Timur-Barat atau orientasi bangunan Utara-Selatan (memanjang Timur-Barat).

Selain itu ada efek ketebalan dinding terhadap suhu sekitarnya. Untuk ketebalan dinding $10 \mathrm{Cm}$, suhu ruang dalam terendah hampir selalu berada di bawah suhu luar. Semakin tebal dinding, variasi suhu udara di berbagai waktu dan orientasi makin rendah. Dinding tebal membuat fluktuasi suhu semakin kecil. Penambahan sebuah beranda di muka rumah akan menjadi sebuah perlindungan terhadap silaunya sinar matahari. Bilamana tidak memungkinkan, setidaknya berilah atap teritis yang lumayan lebar. Sebagai penahan panas, dinding-dinding rumah diberi cat berwarna putih atau warna muda lainnya. Warna yang muda dan warna putih akan memantulkan cahaya sehingga penyerapan panas berkurang.

\section{Perencanaan Rumah Terhadap Arah Angin}

Untuk menambah sejuk di dalam rumah atau bangunan, tempatkanlah rumah atau bangunan tersebut sedemikian rupa sehingga jendela-jendela, pintu, atau lubang-lubang ventilasi menghadap arah angin. Dengan demikian, rumah atau bangunan tersebut mendapatkan peranginan silang. Hindarkanlah ruang-ruang mati, yaitu ruang-ruang yang tidak terkena atau tidak dapat dilalui oleh angin atau cahaya siang.

\section{Perencanaan Rumah Terhadap Pola Hujan}

Pola hujan sangat erat hubungannya dengan arah angin. Dari segi perencanaannya, rumah sudah cukup terlindung dari hujan bilamana atap rumah tidak tiris dan bocor serta bilamana lembab tidak naik ke lantai atau ke dinding. Atap diberi teritis untuk menghindari seluruh dinding menjadi basah. Bagian bawah dari dinding dapat diberi konstruksi tembok dengan adukan yang tahan air. Di samping itu usahakanlah agar halaman memiliki pembuangan air yang baik sehingga setelah hujan reda, air tersebut tidak tergenang dan menyebabkan halaman menjadi becek (tidak kering).

\section{Perencanaan Rumah Terhadap Bencana Alam}

Kejadian bencana alam seperti gempa bumi, gunung meletus, dan banjir tidak dapat diprediksi, bahkan dapat terjadi secara tiba-tiba. Manusia dapat menghindari dan mengurangi akibat kerusakannya terhadap rumahnya dengan memilih umpamanya konstruksi bangunan yang tahan gempa. Tetapi hal ini lebih penting diaplikasikan untuk bangunan dengan konstruksi berat seperti gedung yang bertingkat. Bangunan dengan konstruksi yang sederhana seperti rumah, sifatnya sudah merupakan konstruksi yang aman. Meskipun demikian, demi keselamatan, taatilah petunjuk-petunjuk keamanan lainnya dari pihak yang berwenang pada saat-saat darurat.

\section{Perencanaan Rumah Terhadap Bahaya Kebakaran}

Hubungan manusia dan api sangat erat. Bilamana kurang hati-hati maka api dapat mengakibatkan kebakaran. Asal terjadinya kebakaran dapat bermacammacam, mulai dari puntung rokok, petromax atau pelita yang tumpah atau jatuh, kompor atau tungku di dapur meledak. Bilamana asal mula bahaya tersebut disebabkan oleh minyak yang tumpah, penanganan pemadamannya janganlah disiram oleh air. Hal tersebut dapat menjalarkan minyak yang sedang terbakar meluas. Oleh sebab itu gunakanlah karung basah atau pasir yang ditutupkan pada nyala api. Di dapur dapat dilakukan pencegahan terhadap bahaya 
kebakaran dengan tidak meletakkan tungku terlalu dekat dengan dinding rumah yang terbuat dari bahan bangunan yang mudah terbakar. Bila dinding terbuat dari bilik anyaman bambu lapisilah dengan lembaran seng di dekat tungku itu berada. Selain itu, usahakanlah agar keadaan dapur tetap bersih. Lampu petromax atau pelita diberi cerobong agar tidak mengotori dinding.

7. Perencanaan Rumah Terhadap Gangguan Binatang (Serangga, Kuman dan Jamur)

Ada binatang tertentu meskipun tidak buas, namun berbahaya bagi manusia antara lain nyamuk, tikus, ular, serangga, rayap, dan kumbang yang memakan kayu, serta jamur dan jenis-jenisnya yang merusak rumah. Terpenting adalah pemeliharaan yang baik sehingga gangguan tersebut dapat dihindari dan kesehatan rumah tetap terjamin.

\subsection{Hasil Pre-Test dan Post Test.}

Proses pelatihan diarahkan pada proses pemahaman mereka terhadap tata bangunan dan lingkungan. Hasil test menunjukkan 2 kondisi, yaitu kondisi rumah tinggal masyarakat yang mereka nilai sendiri dan kondisi pemahaman mereka terhadap lingkungan rumah tinggal mereka. Hasil test menunjukkan bahwa pemahaman terhadap tata lingkungan yang ideal belum sepenuhnya dipahami. Mereka berpendapat yang baik adalah yang biasa mereka lakukan. Sesungguhnya yang baik adalah yang sesuai dengan peraturan terutama kesehatan lingkungan.

\section{Kesimpulan dan Saran}

Desa Cikole merupakan desa pegunungan yang memiliki karakteristik masyarakat petani dengan kondisi sumber daya alam yang potensial untuk suatu pusat penyediaan hasil pertanian ke Kota Bandung. Akan tetapi perilaku masyarakat masih belum memperhatikan lingkungan tempat tinggalnya. Terbukti dengan jumlah penyakit ISPA yang mendominasi penduduk menunjukkan kesehatan lingkungan belum diperhatikan. Demikian pula hasil Pre Test menunjukkan bahwa tata bangunan dan lingkungan yang mereka lakukan adalah tata bangunan dan lingkungan sepemahaman mereka saja. Hasil Post Test setelah pelatihan berlangsung menunjukkan hasil yang cukup signifikan tentang pemahaman tata bangunan dan lingkungan.

Diharapkan pada masa mendatang, kegiatan pelatihan tata bangunan dan lingkungan dapat mendorong masyarakat Desa Cikole berperan aktif dalam menjaga dan menatakelola lingkungannya agar sesuai dengan kaidah perencanaan yang baik. Untuk meningkatkan kepedulian masyarakat terhadap lingkungan sekitarnya dibutuhkan beberapa proses pengabdian masyarakat yang tidak hanya berupa pelatihan tetapi sudah pada kegiatan pendampingan.

\section{Daftar pustaka}

Bappeda Kabupaten Bandung Barat. (2013). Materi Teknis Rencana Detail Tata Ruang Tahun 2011- 2031. Bandung: Bappeda.

Hindersah, Hilwati. Kurniasari, Nia. Safitri, Ira. dan Burhanuddin, Hani. (2014).

Membangun Kader Pemberdayaan Masyarakat Di Desa Cikole, Kecamatan Lembang, Kabupaten Bandung Barat. Prosiding SNaPP2014 Sains, Teknologi, dan Kesehatan, Hal 133-138. 
Keputusan Menteri Kesehatan Republik Indonesia No. 829/Menkes/SK/VII/1999 tentang Rumah Sehat.

Peraturan pemerintah No 36 Tahun 2005 tentang Pelaksanaan UU no 28 tahun 2002.

Peraturan Menteri PU No 06/PRT/M/2007 tentang Pedoman Rencana Tata Bangunan dan Lingkungan.

Sargent, Frederic O. Lusk, Paul. Rivera, Jose A. Varela, Maria. (1991). Rural Environmental Planning For Sustainable Communities. Washington, D.C, Island Press.

Shaw, Marvin, E and Philip R Costanzo.( 1985). Theory of Social Psychology, Singapore, McGraw-Hill Book Company.

Sugandhy, Aca, (1999). Penataan Ruang Dalam Pengelolaan Lingkungan, Jakarta, Gramedia

Soehartono, Irawan. (2002). Metode Penelitian Sosial, Bandung, Remaja Rosdakarya.

Undang-Undang No 28 Tahun 2002 Tentang Bangunan Gedung. 